\title{
The Effect of Directed Reading Thinking Activity In Cooperative Learning Setting Toward Students' Reading Comprehension Of The Eleventh Grade Students
}

\author{
Arisetyawati, S. A. Kompyang \\ Ganesha University of Education \\ Arisetyawati46@gmail.com
}

\begin{abstract}
This research was aimed at investigating whether there was a significant effect on reading comprehension of the eleventh grade students who were taught by using Directed Reading Thinking Activity in Cooperative Learning Setting and who were taught by using Directed Reading Thinking Activity only. The research was an experimental research with Post-Test Only Control Group Design. The research was conducted at SMA N 3 Singaraja. The population of this research was the eleventh grade students in academic year 2016/2017 with the samples of 65 students who were selected through random sampling technique. The data were collected by using reading comprehension test. The obtained data were analyzed by using t-test assisted with SPSS 22.0. The result of the research showed that there was a significant effect on reading comprehension of the eleventh grade students in which the students who were taught by using Directed Reading Thinking Activity in Cooperative Learning Setting achieved better reading comprehension than who were taught by using Directed Reading Thinking Activity only $\left(\mathrm{t}_{\mathrm{obs}}=4.056, \mathrm{p}<0.05\right)$.
\end{abstract}

Keywords: cooperative learning, directed reading thinking activity, reading comprehension

\section{Introduction}

For the past decades, English has grown into the main language for global communication. English is a global language which is understood and spoken almost in every part of the world. Global language essentially refers to a language that is learnt and spoken internationally. It is one of essential means to communicate and express ideas among people from different countries. It can not be denied that a tendency toward the use of English as global language has shown a great importance. Almost all international activities are using English as the main language whether it is in the fields of education, economy, business, politics, social, or culture. As the time goes by, people are required to master English in order to be able to compete and socialize in this global era. English become a necessity for people around the world to learn. Many opportunities in international sector are created when people mastered English. English opens opportunities to get a better job, school exchange programs, or even career development. As a means of global communication, people should master English both in spoken and written English.

English gives a big impact in educational field, particularly in terms of global literacy. Literacy is the basis of all learning. Literacy has never been more necessary for development of a person to access today's knowledge. People need to be literate as the information takes the main role in today's world. Being literate means that people are able to read and write. By having those abilities, people are able to obtain information and communication easily. Nowadays, global literacy requires English as an important means for global communication. Most of the sources of information in the world are using English as the main language such as books, textbook, newspaper, online learning, academic article and journal, etc. Therefore, knowing and learning English in this era have become essential.

English in Indonesia is taught and learnt as a foreign language. According to PERMENDIKNAS No.22, 2006 and PERMENDIKBUD No.64, 2013 tentang Standar Isi Satuan Pendidikan, English is considered as compulsory subject that should be taught at school. In relation to that, Indonesia has been carrying out teaching English as a Foreign 
Language almost in all level of schools, starting from elementary school until university. The goal of teaching English as a foreign language in Indonesia is none other than making the learners to be able to communicate using English both in spoken and written way as the means of communication. The learners are not only expected to know the pattern and the rule of the language, but also to use the language in real communication.

Reading is one of the language skills in learning English that should be mastered by students. Reading skill is categorized as receptive skill which is given a priority in the language curriculum. Celce and Murcia (2001) as cited in Sudarmawan (2013: 1) state that reading is probably the most important skill for second language learners in academic context. Reading becomes very essential to be mastered by the students since most of the subject matters in the school begin with printed material or text book and most of the students' tasks at school are related to reading activity. Students will not be able to master the other language skills without reading. Furthermore, reading is the only way to gain new information and improve their knowledge. Reading helps students to open the door of many opportunities and empower them with knowledge.

William (1984:2) defines reading as a process whereby one looks at and understands what has been written. The readers have to use their ability to get information and understand what has been written in a text. It is a complex skill that required the coordination of a number of interrelated sources of information. In other words, reading is an activity which has a purpose to get general or detail information from a written text. Students need to comprehend what they read in order to understand the information of the text.

Comprehension is the main objective of reading. Comprehension is simply defined as the ability to understand certain information. Students need to comprehend the text that they read in order to get the meaning of the text. Students can not get the information or the message of the text without comprehending the text properly. Grabe and Stoller (2013: 11) define reading comprehension as the ability to understand and interpret the meaning of a text. It can be said that reading comprehension is a process of constructing and understanding meaning, information or a message from a certain kind of text.

Reading comprehension become more important as students enter the educational system. Teachers frequently expect their students to search information from books, internet, as well as newspaper. In addition, many tests are required students to comprehend what they read in order to get the needed information. Indeed, reading comprehension should be taught at school in order to increase students' ability in understanding a certain text. The effective reading comprehension process involves both of the teachers and students in communicative language learning. It is important to involve active thinking activity in reading comprehension such as making prediction to the text that they are going to read in order to build students' creative thinking.

According to Renn (1999:7), in a majority of classrooms today, reading instruction is text-centered and does not provide for direct comprehension instruction. Teachers typically use textbook questions to check the students' understanding of a certain text, but rarely teach students the strategies and skills necessary to comprehend what they have read (Durkin, 1979; Pearson, 1987 as cited in Renn, 1999:7). Most of English teachers only ask their students to read a certain text and then answer some provided questions individually. Teachers rarely involve their students to think critically about what they have read in order to comprehend the text. The monotone activities in teaching reading also make the students bored. Besides, the lack of students' willingness to read also becomes one of the difficulties that commonly found. The lack of students' willingness to read may cause by the uninteresting text or the monotone activity that the teacher give to the students. That kind of activity is considered as conventional strategy. Unfortunately according to Tivnan \& Hemphill (2005) as cited in Al Odwan (2012:138), conventional and text-centered classrooms 
do not provide instruction in the skills and strategies necessary for students to learn how to comprehend text.

Reading comprehension instructions include the instruction in specific comprehension strategies and opportunities to read, write, and discuss texts (Duke and Pearson, 2008:208). Students' reading comprehension can be built by providing them with extensive opportunities to practice reading and increase their sense in recognizing and understand words in the text. In order to improve students' reading comprehension teachers need to use creative and innovative way to make the students understand the text easier.

As one of the main sources who can help learners improve their reading comprehension, teachers try to apply a wide variety of techniques in teaching reading. Traditional reading instructions such as asking the learners to read a certain text, find out the meaning of the text, and answer the provided questions are no longer used by teachers in language teaching. Instead of using conventional way, English teachers try to apply more innovative teaching strategies in teaching reading in foreign language classroom. In relation with teaching reading in foreign language classroom, there are various strategies, techniques, and media that have been proposed by many experts to develop the students' reading comprehension. One of the many teaching strategy that has been developed is Directed Reading Thinking Activity.

Directed Reading Thinking Activity (DRTA) is one of innovative strategies that can be used by the teacher to teach reading comprehension. This strategy is developed by Russell Stauffer in 1969. Directed Reading Thinking Activity is a refinement from the previous strategy which is Direct Reading Activity (DRA). According to Stauffer as cited in Renn (197:7), DRA does not provide activities that engage students in reading a certain text critically. Therefore, DRTA is developed to promote active reading comprehension and engage students to think critically to understand a text. In Directed Reading Thinking Activity (DRTA), students are guided through the process of making predictions, silent reading, and confirming or refuting their predictions. Through those processes, students are expected to be active, critical and thoughtful readers. Tierney at al. (1995) as cited in ElKoumy (2006:5) states that DRTA is a strategy that can be used to build independent readers and learners. Besides, DRTA strategy also involves students in using higher critical thinking skills. This skill includes making connection between related elements of the text, confirming the predictions and creating logical conclusion. Since reading involves students to understand and construct their own interpretation to a text, Directed Reading Thinking Activity (DRTA) will be an appropriate strategy to be used in teaching reading comprehension.

Many researchers have proved that the use of DRTA is a good strategy that can be used in teaching reading comprehension. One of the researches about Directed Reading Thinking Activity (DRTA) has been conducted by Wardana (2015) in eight grade students at SMP N 4 Singaraja in form of classroom action research (CAR). This study was conducted to improve the reading comprehension of eight grade students. The result of the study showed that DRTA could improve students' reading comprehension. However, according to Wardana (2015: 49), the implementation of the use of DRTA only makes the situation of the classroom uncontrollable because the students try to answer the researcher at the same time. Not all of the students were involved in the learning process. It can be seen that DRTA is not effective if it is applied in a class which has many students such as in Indonesia, because the teacher will have difficulties in facilitating the students in the teaching and learning process. In addition, the use of DRTA only doesn't provide interaction among the students. Whereas, the interaction that occurs between the students will maximize their learning better than they just reading the text individualy. The use of cooperative learning is one way to get everyone in the classroom involved in the learning process. Therefore in this study, DRTA was 
implemented in cooperative learning setting in order to maximize the positive effects offered by DRTA toward students' reading comprehension.

Cooperative learning is a method that demands learners to work in group. According to Johnson at al. (1991:3), cooperative learning involves small groups so that individuals work together to maximize their own and each others' achievement. This learning concept allows small groups of students to work together to help themselves and their teammates to learn. Additionally, cooperative learning can give learners practice in problem solving in a low risk environment because it is much less threatenening to make a mistake in front of two or three peers than in front of whole class (Killen, 1996:81). Students will have less anxiety when they take part in class activities. Because of its advantages, the use of cooperative learning is considered as one of the teaching strategies that widely applied in language teaching class.

From the facts above, the use of Directed Reading Thinking Activity in Cooperative Learning setting is theoretically good for teaching reading comprehension. It will stimulate the students in understanding and comprehending a certain text easier. Students will realize that learning reading will become more enjoyable whet it is studied cooperatively. Considering the use of Directed Reading Thinking Activity in Cooperative Learning can offer greater benefits upon students' reading comprehension, the researcher was interested in investigating whether or not the implementation of DRTA in Cooperative Learning Setting contributed significant effect to students' reading comprehension. This research focused on the effect of DRTA in Cooperative Learning Setting on the eleventh grade students' reading comprehension at SMA Negeri 3 Singaraja in the academic year 2016//2017.

In accordance with the explanation above, the objective of this study was to investigate whether there was a significant effect on the reading comprehension of the eleventh grade students who were taught by using Directed Reading Thinking Activity in Cooperative Learning Setting and who were taught by using Directed Reading Thinking only.

Theoretically, the findings of this study are expected to enhance the theory of teaching technique in English and support evidence to the existing research findings which revealed the importance of having and experimenting different strategy concerning teaching reading comprehension.

\section{Methods}

This study was an experimental study with Post-Test Only Control Group Design. This design involves two sample groups, those were experimental and control group. The treatment is given only to experimental group, and both groups are measured on the post test. In this type of research design, it only considered post-test score in data analysis, while the pre-test score (students' summative score from the previous semester) was only used to find out the normality and homogeneity of the sample.

The population of this study was the eleventh grade students of SMA Negeri 3 Singaraja at the first semester in academic year 2016/2017 and 65 students of eleventh grade students were selected as the sample through random sample technique. Normality test was conducted in order to know whether students' score of the two classes were normally distributed or not. Test of homogeneity of variance was also conducted in order to know whether those classes were homogeny or not. Afterwards the results of the normality test and homogeneity of variance test showed that the two classes were in normal distribution and homogeneous. Then t-test was conducted to make sure that both of the groups had no significant difference or had equal level before doing the treatments. After making sure those chosen classes were proper as the sample, lottery was used to determine which group would be the experimental group that taught by using Directed Reading Thinking Activity in Cooperative Learning and which group would be the control group that taught by using 
Directed Reading Thinking Activity only. The result of the lottery was XI IBB 2 was as the control group and XI IBB 3 as the experimental group.

There were two kinds of instrument used in this study, namely lesson plans and reading comprehension test. Lesson plans were used as guidance for the researcher as a teacher in teaching the two groups. Meanwhile, reading comprehension test was used as posttest to measure the experimental and control group's achievement in reading comprehension. The test was administered at the end of the research.

The treatment was done for 6 meetings in each group and followed by post-test. The data analysis involved descriptive and inferential analysis. Descriptive analysis aims at describing the data by measuring median, mode, range, mean, variance and standard deviation. Meanwhile, inferential statistical analysis aims at finding out whether the differences of mean score of the two samples were significant or not. Descriptive and inferential statistical analysis was assisted with SPSS 22.0.

\section{Findings}

\section{Findings and Discussions}

The summary of descriptive analysis is presented as follows:

Table 1. The distribution of data

\begin{tabular}{|c|c|c|c|}
\hline \multirow[t]{2}{*}{ No } & \multirow[t]{2}{*}{ Statistics } & \multicolumn{2}{|c|}{ Groups } \\
\hline & & Experimental & Control \\
\hline 1 & Mean & 73.63 & 62.73 \\
\hline 2 & Median & 73.00 & 63.00 \\
\hline 3 & Mode & 70 & 60 \\
\hline 4 & Standard of Deviation & 8.39 & 12.75 \\
\hline 5 & Variance & 70.50 & 162.64 \\
\hline 6 & Range & 26 & 47 \\
\hline 7 & Maximum Score & 86 & 80 \\
\hline 8 & Minimum Score & 60 & 33 \\
\hline
\end{tabular}

The above table showed that the mean score of students who were taught using Directed Reading Thinking Activity in Cooperative Learning was 73.63. Meanwhile, the mean score of the students who were taught using Directed Reading Thinking Activity only was 62.73. Based on the result of descriptive statistics analysis, it can be inferred that the students who were taught using Directed Reading Thinking Activity in Cooperative Learning performed better reading comprehension than the students who were taught using Directed Reading Thinking Activity only.

In this study independent sample test (t-test) was used to test the hypothesis since the data was normally distributed and homogeneous. The data was administrated by using SPSS 22.0. The summary of the calculation is presented as follows:

\begin{tabular}{|c|c|c|c|c|}
\hline Variable & df & $\mathbf{T}$ & $\begin{array}{l}\text { Sig. } \\
(2- \\
\text { taile } \\
\text { d) }\end{array}$ & Remark \\
\hline $\begin{array}{c}\text { Reading } \\
\text { Comprehensio } \\
\mathbf{n}\end{array}$ & 63 & 4.056 & .000 & $\begin{array}{l}\mathrm{H}_{0} \text { is } \\
\text { rejected }\end{array}$ \\
\hline
\end{tabular}

From the table above, it can be seen that the $\mathrm{t}_{\mathrm{obs}}$ was 4.056 and the significance value was .000 . Since the value of $\mathrm{p}(.000)<0.05$, the null hypothesis was rejected. It meant that 
there was significant effect between the students who were taught by using Directed Reading Thinking Activity in Cooperative Learning Setting and the students who were taught by using Directed Reading Thinking Activity only.

In accordance with the findings explained previously, the null hypothesis was rejected. This meant that there was significant effect between the students who were taught by using Directed Reading Thinking Activity in Cooperative Learning Setting and the students who were taught by using Directed Reading Thinking Activity only. The finding showed descriptively that the students who were taught by using Directed Reading Thinking Activity in Cooperative Learning Setting achieved better reading comprehension. It was proven by the result of post-test that was administrated for both groups. The mean score of the students who were taught by using Directed Reading Thinking Activity in Cooperative Learning Setting (experimental group) was 73.63, while the mean score of the students who were taught by using Directed Reading Thinking Activity only (control group) was 62.73. Inferentially, the result of independent sample test (t-test) stated that the null hypothesis was rejected $\left(\mathrm{t}_{\mathrm{obs}}=\right.$ 4.056, $\mathrm{p}<0.05)$. It meant that there was significant effect in which the students who were taught by using Directed Reading Thinking Activity in Cooperative Learning Setting achieved better in reading comprehension test (post-test). In other words, after being analyzed descriptively and inferentially, the students in experimental group achieved better result than the students in control group.

\section{Discussions}

Theoretically, Directed Reading Thinking Activity and Cooperative Learning are not only expected the students to receive the learning material, but also involves the students in searching and finding the learning material by themselves. In Directed Reading Thinking Activity, students are guided through the process of making predictions based on the prior knowledge, reading, and confirming or adjusting predictions in light of new information. Through those processes, students are expected to be active, critical and thoughtful readers. Meanwhile, in Cooperative learning, students work in group of two or more, that they are encouraged and motivated to help one another to learn. Thus, it can be said that cooperative learning promotes a positive interdependence and stresses the centricity of students in the classroom.

Empirically, the implementation of Directed Reading Thinking Activity in Cooperative Learning setting in teaching reading comprehension made the students enjoy and felt more comfortable during the reading process. The students could understand the text easier because they were actively engaged in the reading process through the process of making prediction, silent reading, and confirming the prediction. In line with the explanation above, Richardson and Morgan (1997) as cited in Hashemi and Nazari (2012:56) state that the Directed Reading-Thinking Activity involves students in using higher critical thinking skills. When the students were asked to make predictions, the students tried to use their prior knowledge to connect what they knew with what they were reading. The students tried to find clues in the previous paragraph about the upcoming paragraph. This activity engaged the students to use their critical thinking skills, because they must try to figure out what happen in the next paragraph and relate it with the previous paragraph. In addition, the students also should know the reason why they made such kind of predictions.

Implementing the Directed Reading Thinking Activity in Cooperative Learning setting promoted students' active participation and interaction in constructing meaning in reading comprehension which lead them to better learning outcome. Students were encouraged to discuss what they were learning with their friends in the group. As stated by Putnam (1998), by working coopertively students would actually get time to think about, talk about, and process information about the learning material. In addition, Directed Reading 
Thinking Activity in Cooperative Learning Setting forced the students to be active and independent in their own learning. As stated by Killen (1996:80), students will be less reliant on the teacher and more reliant to their own ability to think, seek information, and learn from the other students. Thus, the students helped each other and cooperate to learn. They tried to help each other in predicting the upcoming paragraphs and understanding the text. When the students had better understanding, the students would be easier in finding out the information addressed in reading comprehension test.

The implementation of Directed Reading Thinking Activity in Cooperative Learning setting also helped the students in decreasing their anxiety if they felt not confident in completing the prediction chart. Through working cooperatively, the students could increase their motivation in learning, share their knowledge as well as their understanding about the text. The obvious fact that could be seen during the treatments was that the students who worked in groups (experimental group) were more motivated to learn compared with the students who worked individually (control group). As stated by Felder (2007:34), students who work individualy may tend to delay finishing their assignments, but when they know that others are counting on them, they are motivated to do the work in a timely manner. During the treatments in the control group, the students that worked individually may have difficulties in understanding the text because of some factors. For instance they did not know the meaning of some words, they were afraid of making mistake in predicting the next paragraphs, and they did not have motivation to finish their work. The students who have high achivement were far above, while the students who have low achievement were left behind. In contrast, the students who worked in group showed better performance because the individual ability in cooperative learning motivated the students to help each other to learn. Low achiever students could get benefit from the group in which the students who have better academic achievement would help students with lower academic achievement to learn by explaining and clarifying the material as well as motivate the low achiever students to learn. When they worked in group, it would help the students to eliminate their fear of making mistake in predicting what the next pargraph would be about.

The students who were taught by using Directed Reading Thinking Activity in Cooperative Learning Setting showed good response during the treatments. The low achiever students could get along with their friends, because they could discuss the reading material with their friends in the group and the high achiever students could help them in understanding the text. The students in control group also showed good response, but there were some students that did not participate in the learning activities. Most of the students that were not participated were the low achiever students and the students that could not focus in the class for long time. The researcher often chose and motivated this kind of students to share their predictions in order to help the students to keep focus in following the learning activities.

From the explanation above, it can be seen that the students who were taught by using Directed Reading Thinking Activity in Cooperative Learning setting could achieve better reading comprehension. The result of this study supported the previous study that was conducted by Al Odwan in 2012 who implemented the Directed Reading Thinking Activity through Cooperative Learning on English Secondary Stage Students' Reading Comprehension in Jordan. The result of his study showed that the use of directed reading activity through cooperative learning is more effective in teaching reading compared with the conventional strategy. He also states that the use of Directed Reading Thinking Activity improves students' reading comprehension because these activities are rich with more interactive tasks and consequently provide students with new concepts, ideas, suggestions, styles of thinking. 
Based on the finding and discussion described above, it can be concluded that there was a significant effect on the reading comprehension of the eleventh grade students who were taught by using Directed Reading Thinking Activity in Cooperative Learning setting and who were taught by using Directed Reading Thinking Activity only at SMA Negeri 3 Singaraja in academic year 2016/2017. It was proven that the students who were taught by using Directed Reading Thinking Activity in Cooperative Learning setting achieved better reading comprehension compared with the students who were taught by using Directed Reading Thinking Activity only.

\section{Conclusion}

This study concludes that the implementation of Directed Reading Thinking Activity in Cooperative Learning setting gives a significant effect toward reading comprehension of the eleventh grade students at SMA Negeri 3 Singaraja. The finding shows that the students' score who were taught by using Directed Reading Thinking Activity in Cooperative Learning setting was higher than the students' score who were taught by using Directed Reading Thinking Activity only.

The finding of this study could become the first hand reference for further research in teaching reading in EFL and also in the implementation of DRTA in Cooperative Learning. It is also suggested for the other researchers who are interested in conducting the similar research to replicate this study for students in different grade levels and different context, for example for primary school or junior high school.

\section{References}

Al Odwan, T. (2012). The Effect Of The Directed Reading Thinking Activity Through Cooperative Learning On English Secondary Stage Students' Reading Comprehension. Jordan International Journal of Humanities and Social Science, 2(16), pp. 138-15. Retrieved from: www.ijhssnet.com/journals/Vol_2_No_16_Special_Issue_August.../15.pdf

El-Koumy, A. S. A. (2006). The Effects Of The Directed Reading-Thinking Activity On EFL Students' Referential And Inferential Comprehension. Education Resources Information Center (ERIC), USA. Retrieved from: http://papers.ssrn.com/sol3/papers.cfm?abstract_id=2365150.

Brown, H. D. (1994). Principles of Language Learning and Teaching. New Jersey: Prentice Hall.

Duke, N. K., \& Pearson, P. D. (2008). Effective Practices for Developing Reading Comprehension. The Journal of Education, 189(1/2), 107-122. doi: 10.1598/0872071774.10.

Felder, R. M., \& Brent, R. (2007). Cooperative learning. Active learning Models from the analytical sciences, ACS Symposium Series. 970, 34-53. doi: 10.1021/bk-20070970.ch004

Grabe, W. P., \& Stoller, F. L. (2013). Teaching and researching: Reading. Routledge.

Hashemi, M. R., Nazari, M (2012). Cooperative Directed Reading-Thinking Activity and Referential- Inferential Reading Comprehension Skills. The Iranian EFL Journal, 8(5) 52-67. doi: 10.13140rg.2.1.2119.952

Johnson, D.W., Johnson R.T., \& Smith, K.A. (1991). Cooperative Learning: Increasing College Faculty Instructional Productivity. ASHE-ENC Higher Education Report No.

4.Washington, D.C.: The George Washington University, School of Education and 
Human Development.

Killen, R. (1996). Using Cooperative Learning as a Teaching Strategy . In Effective Teaching Strategies: Lesson from Research and Practice (pp. 77-96). Wentworth Falls: Social Science Press.

PERMENDIKBUD No.64, 2013 tentang Standar Isi Satuan Pendidikan. Jakarta: Menteri Pendidikan dan Kebudayaan.

PERMENDIKNAS No.22, 2006 tentang Standar Isi Satuan Pendidikan. Jakarta: Menteri Pendidikan dan Kebudayaan.

Putnam, J. W. (1998). The Process of Cooperative Learning. In Cooperative Learning and Strategies for Inclusion: Celebrating Diversity in the Classroom (pp. 17-47). United States: Paul H. Brookes Publishing Co.

Renn, Connie Eilar. The Effects of the Directed Reading Thinking Activity on Second Grade Reading Comprehension" (1999).Masters Theses Paper 456. Retrieved from: http://scholarworks.gvsu.edu/cgi/viewcontent.cgi? article $=1479 \&$ context=theses.

Sayukti, Heny. (2015). The Effect of Guided Writing Strategy Facilitated with Short Documentary film on writing Copetency of the Eleventh grade Students of SMA Negeri 1 Singaraja in Academic Year 2014/2015. Unpublished Thesis. Universitas Pendidikan Ganesha.

Sudarmawan, I.P.Y. Tantra, D. K., \& Marhaeni, A. A. I. N. (2013). The Effect of Grafic Organizers And Text Types on The Students' Reading Competency at SMAN 8 Denpasar. Jurnal Pendidikan Bahasa Inggris, 1. Retrieved from: http://119.252.161.254/e-journal/index.php/jpbi/article/view/495

Wardana, Satria (2015). Improving Reading Comprehension Ability of the Eight Grade Students of SMP N 4 Singaraja by Using Directed Reading Thinking Activity (DRTA) Strategy in Academic Year 2015/2016. Unpublished Thesis. Universitas Pendidikan Ganesha. 